\title{
事例ベース形推論による二次系統の 事故時復旧支援方式
}

$\begin{array}{llllll}\text { 正員 } & \text { 奥 } & \text { 田 } & \text { 健 } & \text { 三 } & \text { (宇都宮大) } \\ \text { 非会員 } & \text { 渡 } & \text { 辺 } & \text { 博 } & \text { 芳 } & \text { (宇都宮大) } \\ \text { 非会員 } & \text { 山 } & \text { 㥓 } & \text { 勝 } & \text { 弘 } & \text { (宇都宫大) } \\ \text { 非会員 } & \text { 馬 } & \text { 場 } & \text { 敬 } & \text { 信 } & \text { (宇都宮大) }\end{array}$

\section{1. まえがき}

電力䒺統を経消的かつ高信頼度をもって速用するた めに種々の施策が講ざられており，系統操作について 毛目動化加准んでいる。しかし，広籍圈にわたる停電 事故に伴う復旧操作は，系統条件のもつ多様性のため 自動化は困難であり，婵転員の判断に妕だねら机る璂 合が多い。運転員には停電という異常事態のもとで, 運用規則や経験に基づき，迅速・的礁に処置するこ之 が要求されるので，その意思決定を支援し，負担の俥 减を図ることが望まれる。復旧操作は回路網の物理的 条件子運用規則や経験などに基ついて行わ机るので， 知識工学的手法の適用が效果的であると思わ机る。

事故洔の状態の推移は，事故発生，保護装置動作， 事故推定を経て復旧操作红入る。著者弓山復旧操作代 着目して，さきにプロダクションシステムを用いた二 次柔統における事故時復旧操作支援方式について報告

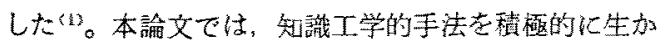
すため，以下に述へるような方法をとった。すなお 方，熟練した運枟員の経験過去に得ら机罗当と思 われる復旧案を事例として計算機に記憶させておき， 当該事故に対して，それに類似の專例の復旧案を参照 し，復旧案を迅速に尘成しようとするものである。事 例の復旧案は数種類のフレームのグンフの形で表現さ

Fault Restoration Operation Scheme in Secondary Power Systems using Case-Based Reasoning. By Kenro Oktda, Member, Hiroyoshi Watanabe, Non-member, Katsuhiro Yamazaki, Non-member \& Yoshinobu Baba, Non-member (Utsunomiya University).

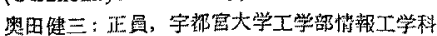

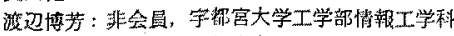

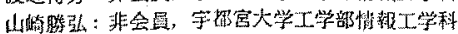

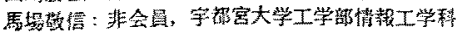

れ，これらの策合加事例ベースとなる。事例ベースに よる推詇方法については，最近注目を集めている課題 の一つで，事例ベースの自動生成やアクセス法などの

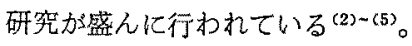

実現した復旧煘作支援システムには，上述の事例へ ースに上る復旧案作成部のほか，一般的な復旧論理を 組迄んだ复旧案作成部があり，事例バースを被完して 動作する。また，得られた復旧案が電王や過目荷条件 を渾たしているか否かを険証するための潮流計算部や マンマシンインタフェース部を有する。以下，本諭女 では，主上して事例ベースによる復旧案の作成法につ いて述へる(6)(7)。

\section{2. 問題の定義と復旧手順}

〈2.1〉問題の定義対象亡する系統は，電力会 社の一つの支占が管轄する程度の広がりをすつ60 kV 系統を奶象上する。そこには箱数の变跑所が存在し， それらの $60 \mathrm{kV}$ 系笙側で原則しして相互に並列運 転は行わない。また，各部分系統は放射状の整成にな つている。

事故地点は基本的に性意であるが，事故による停 電範囲が広く復旧操作が複雑になると了想される变電 所母線での単一事故とする。なお，同一部分系統内で の多重事故孛取报うことも可能である。また，遮断器 の投入搡作により充電の及ふ鹳囲に含まれる負荷・送 電線・四線をましめて負荷ブロックと呼ぶしにす $3^{(1)}$ 。

復旧操作の万針は，僖電電力の鼠小化，停電時間の 短縮，できるだけ㗊故前の系統構成に近い形に復旧す ることを目指す。

〈2.2〉復旧手順 上記の復旧操作方針に基づき, 


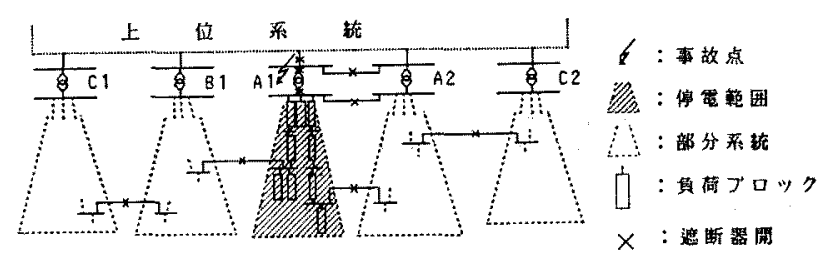

（復旧掫作闻始前の状態）

図 1 二次系統図

Fig. 1. Secondary power system diagram.

復旧方策立案の手順定図 1 により述べる。

(1) 停電した部分系統 $A 1$ 亡同一变電所の健全 側の部分系統 $A 2$ 加 $A 1$ 亿送電する。

(2) 部分系統 $A 1$ に直接隣接する部分系統 $B 1$ 加ら送雪する。

（3）以上でもなお停電が解消しない場合は，部分 系統 $B 1, A 2$ 亿直接瞵接する部分䌽統 $C 1, C 2$ に $B 1, A 2$ の負荷の一部它切換えて $B 1, A 2$ 加 $A 1$ 八の送電電力の增強龱る（負荷切換えと呼沙）。

（4）以上でなお送電電力が不足する場合は，重要 負荷を優先的に復旧する（部分復旧と呼ぶ。

\section{3. システム構成}

〈3.1〉 システムの概要 本システムは図2 に示 す構成からなる。以下，各構成部の磈要について述べ る。

（1）制御部制御部は全体の制御老行う部分で ある。制御部が事故入力老取ると，保護装置動作案 の作成と，必要ならそれに対する訂正入力を受付け

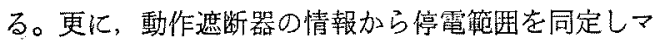
ンマシンインタフェース部の CRT 上飞表示する。

(2) 系統条件などの知謧 采統内の各種要素, 系統の接続条件，負荷分布，ならびにて机らをむとに 加工された復旧操作に必要な情報が格納されており，

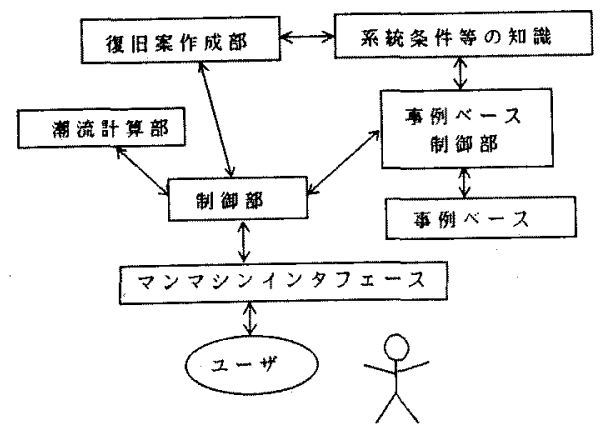

図 2 システム構成図

Fig. 2. Diagram of system construction.
復旧案作成部や事例ベース制御部からの参照や制御を 骎ける。

（3）復旧案作成部一般的な采統対象に， $\langle 2.2\rangle$ 節の手順に基づき復旧案を作成する部分で， 〈3.2〉節で述べる。この復旧案作成部では復旧案を網 羅的に生成し，そのなかから最適な案を選択できるよ うにしている。復旧案作成の出力としては, 次に示す 情報が得られる。

（i）復旧用電源とそれによって復旧される㥧荷ブ ロック・母線などの要素りスト, 復旧負荷合計

（ii）負荷切換えが行われる場合は，負荷切換用電 源と切換えられる要素リスト，切换負荷合計

(盕) 操作される遮歁器りス卜

（4）事例ベースとその制期部 典型的な倳例に 関する復旧案が格納されている事例ベースに対して, 参照，探索，設定，更新，削除などの各種制御を元 い，当該事故に対する復旧案を作成する。

（5）マンマシンインタフェースＣRT 画面に 靑示された系統図上に，復旧操作に必要な各種情報が 示される。また，各種復旧案とそれに対する潮流計算 結果を裁形式で見るとしができる。

（6）潮流計算部復旧案立案の段階では有效 䇴力だけに着目しているので，潮流計算部に㧍いて Newton-Raphson 法により母線電圧や線路容睹に関 する制約条件を澏たしているか否かを調べる。

〈3.2〉処理の概要復旧案の作成における処理 全体の流れを図 3 に示す。同図において，1〜2は前

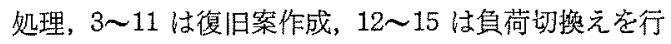
う部分である。まず，前処理が終ると，前節(4)項で 述べた事例ベース制御部が起動される。こてで復旧案 が得られれば制御部に制御は医るが，得られない場合 は，前節（3）項で述べた復旧梁作成部に制御が移る。 復旧案が求められると制御部化制御が民り，マンマシ ンインタフェース部の CRT 上に系統図や表形式で復 旧案が表示される。更に，必要に応じて潮流計算部を 起動し，その結果をCRT上に表示可能である。 


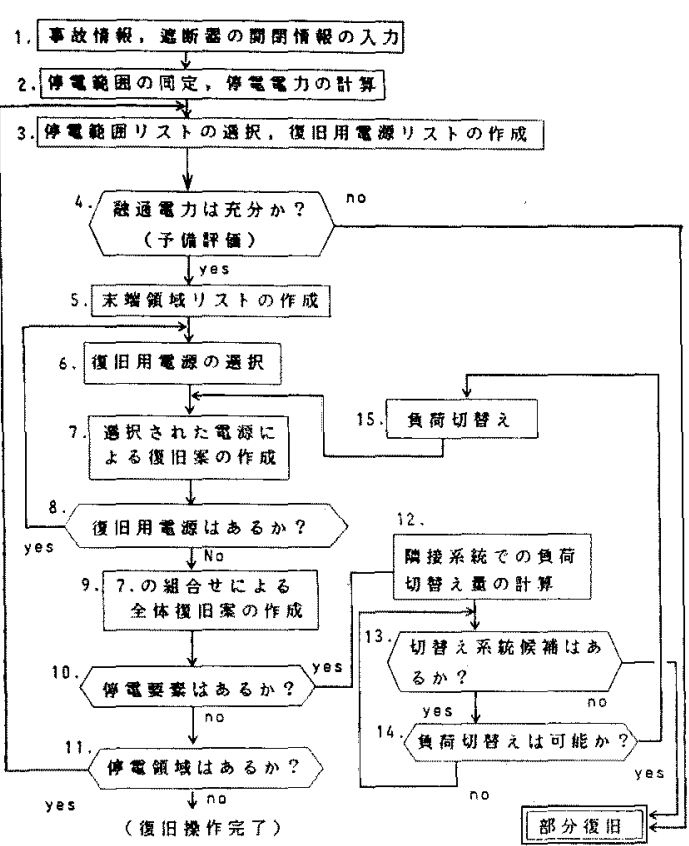

図 3 復旧案作成の流扎

Fig. 3. Flow-chart of generating restoration plan.

前節 ( 3 ) 項の復旧案作成部の処理内容は図 3 の 4 以 降であり，その概要を以下に述べ。7において， 復旧用電源を根とする木を展開して, 復旧要素りスト を求める。9 の全体復旧案作成では，7の電源復旧案 作成で作成した電源復旧案の組合せを行う。な放, 負 荷復旧操作の自由度を高，二重母線に接䌖さ れる負荷ブロックを，互いに相手側に切換えられるよ うにした。目荷切換えには，因4に示すように，同一 変電所 (同図の部分系統 2,3 間) での負荷切換え上 隣接系統（同図の部分系統 $4 ， 5$ 間）での負荷切換え がある。前者, 部分菜統 2 の場合, 変電所二次側母線 飞接統する部分木を部分录統 3 人切換える。すなわ ち, 部分木の真荷合計が部分系統 1 への送電電力增加
量の目標值よりむ大きく，加つそれを部分系統 3 人切 換え可能なら切換えは成功する。切換元不能なら切換 元可能な籍因にとどめる。後者, 部分系統 4 の場合 は，母線または負荷ブロックを根とした部分木を部分 菜統 5 八切換える。部分系統 4 内での負荷切換えの詳 細は, 部分系統 5 が送電可能な電力の範团内で, 同図 に示すように，破線(1), (2)，(3)，‥の順序で切換えを行 j。

\section{4. 事例ベースを用いた復旧案作成}

$\langle 4 \cdot 1\rangle$ 事例ベースの概要 一般に, 事例ベース 班推諭で报う事例の数は膨大であるので，大きな事例 ベースの自動生成や效率的なアクセスが肝要である。 霄力系統に扔いても，保守点検のために一部の設薒が 停止することによる系統の接続状態の変更や，時々刻 刻变化する負荷など，系統状態は多様性に富んでいる ので，復旧操作に関する事例は膨大な数になることが 予想される。しかし，むやみに多くの事例を記憶させ ておくと，記憶量が增えるばかりでなく，事例の探索 に時間がかかり，処理の高速性が揎なわれる。そこ で，同一部分系統での聚故の復旧案のな加加，典型 的な專例を事例ベースに記憶させておく。ここで典型 的な事例上は，春视期のピーク時で設備停止のない条 件において，専門家が決定する復旧案を意味するもの とする。当核事故付対する復旧案を作成する場合は， 事例ベースのな加加ら後述する基準に従って類似の事 例を選択し，事例ベースの復旧案に，必要に応じ修正 を加えて㥏用する。

因5（a）に事例べ一スを用いた復旧案作成のおおま かな流れを示す。まず，停電領域が同定された時点 (図302) で，当膀事故に最も近い事例を事例べー スから選択する。ここで選択の基準は，後述する復旧 案フレームに蓄无られた事故系統，停電領域，事故要 素, 設備停止要素, 停電負荷合計の 5 個のスロットの 值を比較し，等しいスロット值が一番多い事例を選択 するすのとする。次に，当該事故の停電領域を，事例

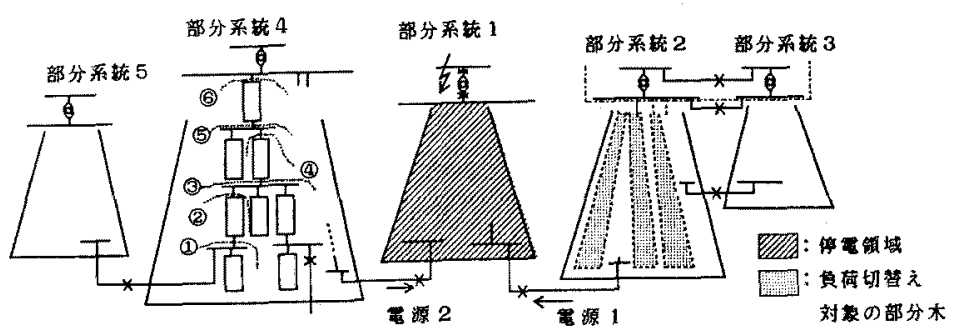

図 4 真荷切換云説明図

Fig. 4. Explanation diagram of change-over of load. 


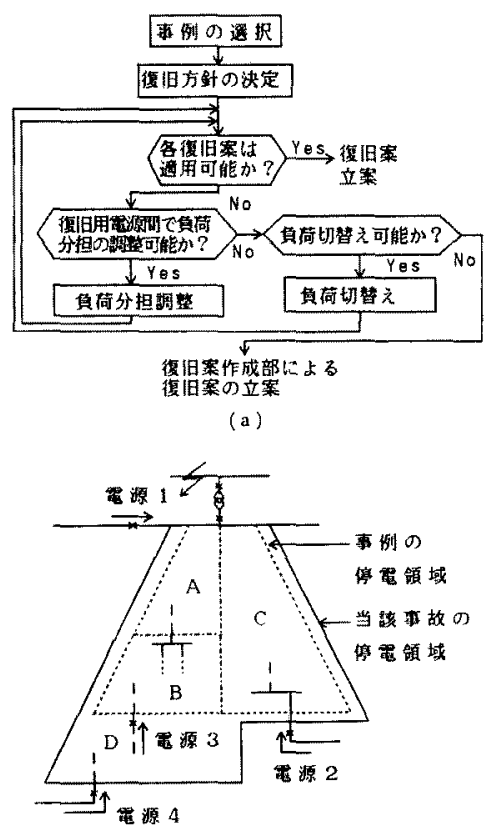

(b)

図 5 專例ベースによる復旧案作成

Fig. 5. Generation of restoration plan by case-based reasoning.

を参考にして復旧用電源別にグループ分けする。これ らの復旧用電源による復旧方針を立てる。その復旧案 が適用可能加否か心調八，不可能な場合は復旧用電源 間での負荷分担の調整，更には負荷切換えによる送電 電力の增強を行い，事例の復旧案を修正して当該事故 に適用する。図 5 (b)仕当該事故の综電領域加事例の 停電領域を包含する場合の復旧案作成の例である。す なわち，事例では電源 $1,2,3$ によ，各々領域 $A$, $C, B$ が復旧されるのに対し，当呟事故では電源 1 ,

$2 ， 4$ に上り各々領域 $A+B, C, D$ が復旧されてい る。

乙の場合，各電源の送電可能電力を考虑して負荷分 担を調整し，復旧頜域が決定される。必要な弓電源の 送電可能電力を增強するために，隣接系統での負荷切 換えが試みられる。

このように，事例ベース制御部は与えられた事例を 基にそれり外の停電事故に対しても復旧案を生成する ための推諭能力をもっている。

〈4.2〉事例ベースの詳細＼cjkstart事例ベースはフレー ム形式により棈築されている。復旧手順に関する具例 を表現するためのフレーム事例フレームと呼ぶとと にする。事例フレームは，復旧案フレーム，復旧用電 源フレーム，電源復旧案フレーム，真荷切換案フレー
ム，全体復旧案フレームの5種類のフレームからな る。

（1）復旧案フレーム＼cjkstart復旧操作に関する事例を 表すための基本的なフレームである。事故情報とし て，等故系統，事故要素，設備停止要素，停電領域， 停電目荷合計などのスロットをすつ。とこで，停電領 域は停電した要素のリストである。復旧操作に関する 情報ししての復旧用雨源スロット，全体復旧案スロッ トは，関連する事例フレームへのポインタをすつ。

（2）復旧用電源フレームそれぞれの復旧用電 源についての情報を表すためのフレームである。電 源，送電電力，添統，停電領域上の接結要素，負荷切 換案，負荷切換えによる堌加電力などのスロットをす つ。負荷切換えにより送電電力が堌加して格れば，負

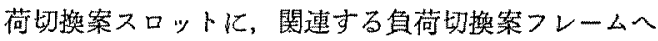
のポインタを与え，真荷切換えによる増加電力スロッ トに電力の增加分が記録される。

（3）電源復旧案フレーム（2）項の復旧用電源 により復旧可能な停電領域中の要素集合を表す。復旧 用電源, 復旧要素リスト, 電源に直按接続する要素, 復旧真荷合訣，余裕電力などのスロットをあつ。こと で, 復旧用電源スロットには関連する復旧用笔源フレ ームへのポインタが入る。電源に直接接続する要素ス ロットは，復旧用電源から直接電力の供給を受りるこ とになる要溸である。

（4）負荷切換案フレーム停電領域に対する復 旧用電源の送電電力を增強するための，健全系統での 負荷切換案を表す。切换用電源，電力増強を図る復旧 用電源，切換系統，鱼荷切換えによる送電電力八增加 量, 切換案, 遮断器操作リストなどのスロットをむ つ。切鳛用電源スロットには関連する復旧用電源フレ 一ムへのポインタが, 切換案スロットには関連する電 源復旧案フレームへのポインタが入る。

（5）全体復旧フレーム，停電頜域に詨する全体 的な復旧案を表すフレームである。電源復旧案, 停電 領域に対する遮断器操作, 負荷切換えによる操作卑含 んだ全体の遮断器操作などのスロットをすつ。

これらのフレームに対して，おるスロットの值の参 照, 設定, 削除, ある条件を満たすフレームの梁索, 祖先／子孫フレームの探索を行うためのフレーム操作 用の述語が定義されている。このほか，if-needed， if-added, if-deleted などのデモンが用意されている。

5 種のフレームからなる等例フレームの一例を図 6 を用いて説明する。(a)図中の(1)〜(5)は上述の各フレ 一ムに対応する。図加ら明かなように，5種のフレー ムをノードとするグラフで構成される。(b)図はとの 


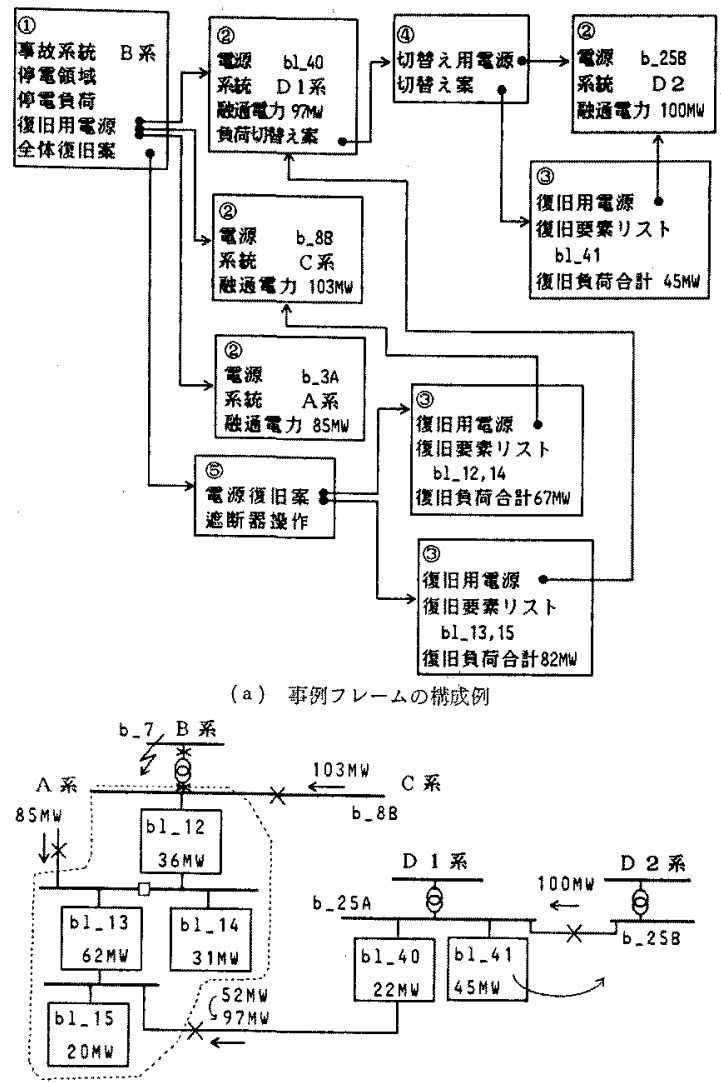

(b) 系統四

図 6 事例フレーム説明図

Fig. 6. Explanation diagram of case frame.

復旧案を系統図上で表現した6のである。この例では， 母線 b-7 の事故により破線で囲まれた部分系統が停 電領域となり，復旧用電源として，C系の $b-8 B$ 加 $103 \mathrm{MW}, D 1$ 系の負荷ブロック bl-40 加ら $52 \mathrm{MW}$ の送電が可能とする。しかし， $B$ 系への送電電力が不 足するために $D 1$ 系加らの送電電力の增強を図る。 すなわち，bl-41 (45 MW) を $D 2$ 系の $b-25 B$ へ負 荷切換えすることにより，D1 系加ら $B$ 䒺への送電 電力は $97 \mathrm{MW}$ となる。従って, 復旧案としては (a)図化示すように, $C$ 系加ら bl-12, 14 (67 MW), $D 1$ 系加ら bl-13，15 (82 MW) を復旧するととを意 味する。

\section{5. 実験ならびに結果の考察}

〈5.1〉実験条件 モデルに選んだ二次系統は 10 個の部分系統からなり，一つの部分系統内の目荷ブロ ック数は 10 以下，一つの部分系統での隣接系統七の 接続可能な箅所は $1 \sim 5$, 一つ負荷ブロック内の負
荷の数は 10 以下である。事故点は変電所高王側母線 とする。更に，1要素の設備停止中の事故や負荷状態 を変化させた場合についても実験を行う。

本システムの復旧案作成化関する部分の規模は，事 例ベース制御部が約 $32 \mathrm{k}$ バイト，事例ベースが約 $28 \mathrm{k}$ バイト(事例数 10)，復旧案作成部が約 $45.5 \mathrm{k}$ バイト， 系統条件などの知識が約 $19 \mathrm{k}$ バイトであり，ワーク ステーション NEWS/NWS-821 上で実験を行う。 使用言語は, 手統き部分の多いマンマ.シンインタフェ ース部, 潮流計算部については $C$ その他はすへて k-Prolog である。

\section{$\langle 5 \cdot 2\rangle$ 実験と考察}

(1) 事例ベース導入の評価モデル系統におい て, 各変電所高圧母線での永久事故を想定して実驓を 行う。表 1 亿部分系統の櫣成, 事例を表すための各種 フレーム数拈よび処理時間を示す。同表に見るよう に，各部分系統ごとに一つの事例（復旧案フレーム） が登録されている。いずれ屯，当酧事故上事例の条件 
表 1 焉例ベースによる復旧案作成奏毁結果

Table 1. Experimental result of generating restoration plan by case-based reasoning.

\begin{tabular}{|c|c|c|c|c|c|c|c|c|}
\hline & $ケ ー ス$ & 1 & 2 & 3 & 4 & 5 & 6 & 7 \\
\hline 管状 & 兌荷ブロック数 & 9 & 1 & 1 & 4 & 8 & 2 & 5 \\
\hline 筧沉 & $60 \mathrm{kV}$ 目線 & 3 & 1 & 1 & 4 & 3 & 1 & 1 \\
\hline & 隣接系統との接続点 & 2 & 2 & 1 & 3 & 5 & 2 & 4 \\
\hline & 征伹のパターン & $1 R$ & $1 R$ & $1 C 1 R$ & $2 R$ & $2 C 3 K$ & $\perp C \perp R$ & $2 R$ \\
\hline & 復旧案フレーム & 1 & 1 & 1 & 1 & 1 & 1 & 1 \\
\hline & 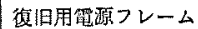 & 3 & 2 & 2 & 4 & 5 & 2 & 3 \\
\hline$\hat{L}$ & 電䃇很旧案フレーム & 1 & 1 & 2 & 2 & 5 & 2 & 2 \\
\hline 1 & 鱼荷切換穼フレーム & 0 & 0 & 1 & 0 & 2 & 1 & 0 \\
\hline 数 & 全体得旧菜フレーム & 1 & 1 & 1 & 1 & 1 & 1 & 1 \\
\hline & 合 㙕 & 6 & 5 & 7 & 8 & 14 & 7 & $?$ \\
\hline & 処玨時間 (s) & 3.7 & 3.2 & 7.1 & 6.8 & 62.5 & 12.0 & 6.6 \\
\hline
\end{tabular}

表 2 復旧案作成部による実鉷結果

Table 2. Experimental result of generating restoration plan by general restoration algorithm.

\begin{tabular}{|c|c|c|c|c|c|}
\hline \multirow{2}{*}{ ケース } & \multicolumn{2}{|c|}{ (a)一つの案を作成 } & \multicolumn{3}{|c|}{ (b) 被数究学作成 } \\
\hline & 時間 $(s)$ & 復旧パターン & 時間( $(s)$ & 最良パターン & 復旧寀数 \\
\hline 1 & 8.4 & $1 R$ & 30.1 & $1 R$ & 27 \\
\hline 2 & 0.7 & $2 R$ & 0.7 & $1 R$ & 2 \\
\hline 3 & 5.0 & $\mathbb{I C I R}$ & 5.0 & $1 C 1 R$ & 1 \\
\hline 4 & 3.1 & $3 R$ & 19.1 & $2 R$ & 8 \\
\hline 5 & 69.4 & $2 C 5 R$ & 126.5 & $2 C 3 R$ & 8 \\
\hline 6 & 8.6 & $1 C 1 R$ & 8.7 & $1 C 1 R$ & 5 \\
\hline 7 & 4. 1 & $3 R$ & 23.5 & $2 R$ & 19 \\
\hline
\end{tabular}

が完全に等しい場合であり，当然，事例の復旧案がそ のまま適用できる。各ケースにより処理時䦥が異なる

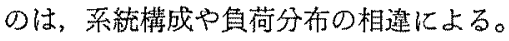

復旧パターンについてみると，ケース 2 と 3 では負 荷ブロックや母線数は同数であるが, ケース 3 では負 荷切換えが必要なため，処理時間分長くなっている。 系統構成が処理時間に及ぼす影響をみると,ケース 3 と6では復旧パターンは同じく $1 C 1 R$ (負荷切換え 1 回, 復旧用電源 1 筒所) であるが, 停電領域の要素 数，負荷切換えを行う要菜数が，ケース6のほうが多 いため，処理時間は長くなる。

表 2 に〈3.1〉節(3)項で述べた復旧案作成部によ る実験結果を示す。得旧案作成部は同表 (b) 亿示すよ うに，複数の復旧案を網羅的比生しているが，同表 (a)では，一つ目の復旧案が得られた時点で処理を終 了させた場合を示している。

復旧案作成プログラムが求めている一つ目の復旧案 は必ずしも最良の案ではなく，最良案は複数案のなか 加ら選択する必要があるので，表 1 と表 $2(\mathrm{~b})$ との比 較をす心゙きである。ここで，最良とは復旧パターンが
最も単純なものとする。とのような観点に立つと，系 統構成が複雑な場合は事例べースによるほうが速く， その有効性を示している。

ことで，事例ベースによる方法が比較的単純なケー スにおいて，姏理が遅くなる理由は次の之おりである。 復旧案作成部は Prolog インタプリタ上で直接実行さ れるが，事例ベース制御部はPrologインタプリタに より動作するフレームシステム上で実行することにな る。従って, 例えばスロット值の参照に扔いて, 目的 のスロットに値がなければ，親フレームのスロットの 参然，デモンなどにより自動的に值を探索するととに なり，その制御の分だけ処理時間は長くなる。

（2）設備停止に対する事例べースの柔軟性系 統条件の変化上して変圧器バンクの設備停止を想定し た場合に，事例ベースに登録した事例で妥当な復旧案 を作成できるか否かについて，炊のような実験を行 う。

図 7 は系統で設備停止が行われていない状態（標準 状態之呼哥）に括いて，B系の変電所高生側母線事故 が生じた場合の復旧案を示している。すなわち, 停電 領域に対して，C系加ら $b l-5,7$ を， $A$ 系加らbl-6 を，D1 系から bl-8 をそれぞれ復旧する。この場合 の復旧パターンは $3 R$ であり，乙れを事例ベースに登 録しておくもの上する。なお， $B$ 系以外の部分系統は 一部の真荷ブロックを集約して簡略化して図示してあ る。

（i）事故系統への送電電力が小さくなる場合

図 7 に括いて，C系の変圧器バンク容量 $665 \mathrm{MW}$ 中の $190 \mathrm{MW}$ 方設備停止中に $B$ 系の变電所高圧側母 線事故が生じた場合を榆討する。C系加ら $B$ 系への送 電電力は標染状態の $103 \mathrm{MW}$ 亿対し $42 \mathrm{MW}$ に低下 する。負荷ブロック $b l-11$ を $E$ 系犆真荷切換えする ことにより, $C$ 系加ら $B$ 系への送電電力を $68 \mathrm{MW}$ に增強する。以下は標準状態之同様汇报えるので, 復 旧パターンは $1 C 3 R$ となる。

（ii）停電領域が拡大寸る場合 図7亿おいて, $A$ 系の変任器バンク $95 \mathrm{MW}$ が設備停止時に $B$ 系の 变電所高压側母線事故加生じた場合を検討する。この 場合は $A, B$ 雨系が停電上なり, 復旧用電源は $C, D 1$ 系㳊限られる。 $C$ 系加らの送電電力は途中の送電線 の容量制限を受けているので, D1 系の負荷ブロック $b l-13$ を $D 2$ 系へ負荷切換えして $B$ 系への融通電力 を $52 \mathrm{MW}$ 加ら $97 \mathrm{MW}$ 增強する。C 系から bl5, 7 (67 MW) を, $D 1$ 系加ら bl-1, 2, 3, 4, 6, 8 (92 $\mathrm{MW})$ を復旧する。この場合の復旧パターンは $1 C 2 R$ となる。 


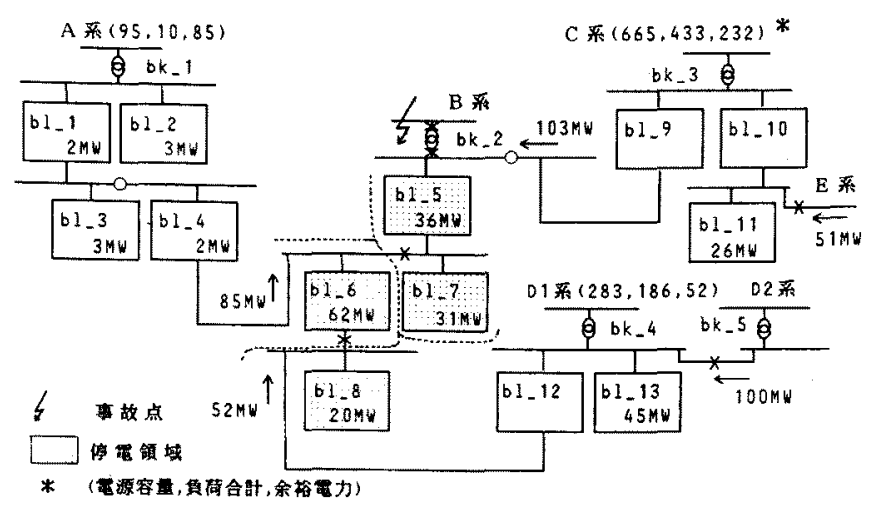

因 7 復旧案に及活す設借停止の影響

Fig. 7. Effect of equipment suspension on restoration plan.

表 3 設備停止による系統状況の変化に 対する復旧案作成の処理時間

Table 3. Effect of equipment suspension on generating restoration plan.

\begin{tabular}{|c|c|c|c|c|c|c|}
\hline$z$ & \multicolumn{2}{|c|}{ 標準状㥎 } & \multicolumn{2}{|c|}{ (i) $0 ケ-x$} & \multicolumn{2}{|c|}{ (i) のケース } \\
\hline 方法 & (a) & (b) & (a) & (b) & (a) & (b) \\
\hline 事倒 & $3 R$ & 8.2 & $1 C 3 R$ & 24.8 & $1 C 3 R$ & 30 \\
\hline 復旧案作成部 & $2 R$ & 19.1 & $1 C 2 R$ & 38.2 & $3 R$ & $2,318.2$ \\
\hline
\end{tabular}

注) (a)：復旧パターン, (b): 処理時間 (s)

以上の実駼結果をまとぬると表 3 のうになる。同 表では, 復旧案作成部を用いて求めた場合併記して ある。事例ベースによる場合，標準状態に比へると両 ケースとも処理時間は多少長くなるが，復旧案作成部 による場合よりるかなり速いことがわかる。復旧パタ ーンについてみると，全体的復旧案作成プログラム によるほうがやや単純なパターンを生成している。て 机は，復旧案を網羅的に生成しているためである。従 って, 事例形推論により最も単純な復旧パターンを得 ようとするならば，ケース（ii）に対する事例を登録す るか，または事例べース制御部の柔軟性，以換えれ ば，推論能力を更に高める必要があるう。なお，事例 ベースのもつ推論能力により, どの程度の系統条件の 変化任追随して妥当な解が得られるかについ，一般 的に判断することは困難である。ここで，妥当な解と は，〈2・1〉節で述べた復旧操作の方釗に基ついて判断 するものとする。

（3）目荷状態の変化注対する事例ベースの柔軟性

電力系統の負荷状態は, 季節, 日, 時間帯などによ り大きく変動する。ここでは, 負荷の標準状態として 春秋の季節を選んでいるが，とれに対して各負荷ブロ ックの負荷の值を一律に $30 \%$ 減と $15 \%$ 增にして実 験を行う。
表 4 負荷状態の変化に対する事例ベース による復旧案作成

Table 4. Effect of load condition on generating restoration plan by case-based reasoning.

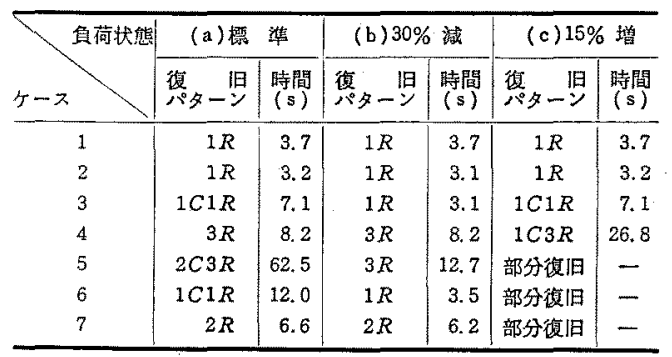

表 4 に事例ベースに上る復旧案作成の処理結果を示 す。標準状態の復旧パターンは事例と同じである。同 表によれば，負荷 30\% 減の場合，負荷切換えが不要 になり，処理時間も短縮されている。負荷 $15 \%$ 增に おいては，標淘状態之同一の蕧旧パターンのほか，負 荷切换えが必要になったり，更には隣接系統からの送 電電力が不足するため，部分復旧になる場合のあると とを示している。

〈5.3〉事例ベース構築についての考察事例ベ 一スに登録する事例の選択基準について考えてみる。 それは，〈2・1〉節で述へた復旧操作の方針氏基づき， 専門家の判断や経験, 更には復旧案作成部で生成され た最良の復旧パターンなどを参考にして，選択するこ とになろう。今回登録された事例の数は比較的少ない ので，予想どおりの事例が選択できた。事例の数が多 くなった場合であ前述の判断基準により比較的容易に 最通な事例が得られると思われるが，多くの事例研究 の結果に基づき選択基準を改良する必要があるう。な お，最適でない事例を選択した場合は，处理時間が延 
びたり，解が得られないととが予想される。登録すべ き事例の数は，今後更に検討要要する驾，事例の選定 基準からみて，各部分采統ごよにたかだか数ケースで はなかるうか。

事例ベース交設計するにあたり，系統条件の変化へ の柔軟性を高めることにより，登録する事例を少なく する方針をとり，妥当と思わ㞦る復旧案を得ることが できた。今後，事例ベース制御部に付与すべき機能， 事例ベース全体の構筑法，更に一般的な復旧諭理に基 づく復旧案作成部との協調という観点加ら毛，更に检 討の余地があろう。

\section{6.むすび}

事例ベースを用いた二次采統によりる事故時復旧支 嗳システムを作成した。亨例ベースに專門家の経験や 過去に得た最良に近い復旧案を登録しておくことによ り，実用性，信頼性の高い復旧案を迅速に生成できる ことを明らかにした。をして，一般的な復旧論理を組 込んだ復旧案作成部による方法と事例べースによる方 法とを比較した場合，系統条件が複雑なほよ゙，後者の ほうが処理時間は短く倀饥ている。また，事例ベース 制御部の推論能力を高め, 類似のケースに対応可能と することにより，事例を比較的少数登録する今回の方
法が有効なことを確認した。

今後の課題としては，更に事例調答を通じて事例に 付与すべき機能，事例べースの構築法，一般的な復旧 諭理に基つく復旧案作成部との協調という観点から， 更に検討を行いたい。

本研究を進めるにあたり，熱心かつ皘極的に協力さ れた本学卒研生中川和三, 加藤孝治, 急谷光代の諸君 に厚く㧍礼申し上げます。

（昭和 63 年 2 月 28 日受付, 同 63 年 6 月 30 日再受付）

\section{文 献}

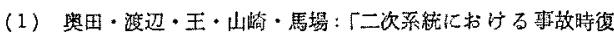
组操作への知識工学の沈用」，需学諭 B， 107，509 昭 6210)

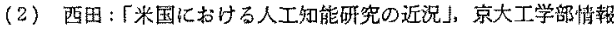
工学教空第 109 回情報工学研究教話会 (昭 62)

(3) W. G. Lehnert: "Case-Based Problem Solving with a Large Knowledge Base of Learned Cases", AAAI-37 (1987)

(4) K. D. Ashley, E. L. Rissland: "Compare and Contrast, A Test of Expertise", ibid. (1987)

(5) A. Ram: "AQUA: Asking Questions and Understanding Answers", ibid. (1987)

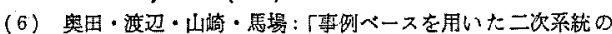
事故時復旧支授システム」，昭 63 電気学会全大，No. 1009

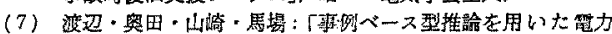
案統事故時復旧支授システム」，昭 63 情報処理学全第 36 回 全大, $7 Q-6$ 